\title{
6. Ideas of Corruption in the Eighteenth Century: The competing conceptions of Adam Ferguson and Adam Smith
}

\author{
Lisa Hill
}

\begin{abstract}
Although the eighteenth century is generally conceived as the age of progress and optimism, many eighteenth-century thinkers believed the world was in its senility. Such fears focused on a concern for the dissipation of virtue and this became one of the most urgent problems of political philosophy in the eighteenth century (Pocock, 1975, p. 462). Like many of their contemporaries in the Scottish Enlightenment, Adam Ferguson (1723-1816) and Adam Smith (1723-90) were intensely interested in the development of commercialism and the accompanying social, political and material changes that were taking place in the latter half of the eighteenth century. Their resulting observations generated, arguably, the two most sophisticated early sociologies to date. But their approaches differed considerably. Although they both perceived in commercialism the potential for corruption, their aetiologies were vastly different. Ferguson, who is well recognised as a thinker absorbed with the problem of corruption, classically understood, was deeply ambivalent about progress. Though he welcomed many of its aspects as both natural and inevitable, he also expressed alarm at some of its effects on virtue and social intimacy. Drawing inspiration from classical sources, he was concerned with how much was lost in the seemingly inexorable march towards progress. By his account, community, social intimacy, intensely emotional friendships and alliances, martial vigour and civil vitality were all casualties of the commercial age.
\end{abstract}

Smith, on the other hand, is rarely associated with standard classical themes of corruption, perhaps because he was basically optimistic about the effects of commercialism. But, as I hope to show here, he also noticed that the commercial age embodied a number of corrupting pathologies. Unlike Ferguson, for Smith, these did not take the forms usually associated with the classical tradition. Smith's vision is basically modern, representing his determination to make a decisive break with the past, a past to which Ferguson remains stubbornly loyal.

One significant aspect of the thoughts of these two figures is that, together, they signpost a transitional moment in understandings of the term 'corruption'. It was during the eighteenth century that the modern conception of corruption came to overtake the classical, and by the nineteenth century this transformation 
had consolidated so that the term 'corruption' was rarely used in the classical sense. That the eighteenth century was a period of flux is reflected in the fact that two contemporaneous figures who were also friends could entertain vastly different understandings of the term. Ferguson represents the past in adopting a standard, classical approach to the topic, whereas Smith is moving towards a more modern, proto-liberal conception.

The disagreements between Smith and Ferguson about what 'corruption' consisted in turn on their more general attitude to progress and the commercial age. For Ferguson, corruption is understood as a progress-induced decline in civic virtue and effective political condition. Smithian corruption consists in violations of the system of natural liberty, including violations that corrupt the naturally self-governing behaviour of individual actors. In other words, corruption is instigated by obstructions to the 'natural' course of progress rather than by progress itself. In consequence, more progress is generally his solution to any of the pathologies of modernity. According to Smith, pre-commercial society generates corruption because of its tendency to discourage individual autonomy on the one hand, and interfere with the natural laws of the market on the other. Amongst these corrupting remnants of pre-commercial stages are political faction and paternalistic forms of governance, which should be purged in order to secure the commercial stage from decline.

\section{Ferguson's approach}

Like many classical authors, as well as more modern ones including Rousseau and Montesquieu, Ferguson conceives moral corruption as a problem of virtue. Loss of virtue was the cost of greatness, and he believed that political decline was more likely in prosperous empires. His declared purpose in writing the Essay on the history of civil society (1767) was 'to describe that remissness of spirit...that state of national debility, which is likely to end in political slavery' (Ferguson, 1996 [1767]a, p. 247).

Ferguson takes his conception of corruption from Polybius, as did Machiavelli. For Machiavelli, it represented any form of deterioration in the quality of government. ${ }^{1}$ Ferguson agreed that corruption could affect people, not only individually but also en masse, denoting pervasive attitudinal and behavioural trends in a given polity (Shumer, 1979, p. 9). Polybius identified two possible sources of decay from natural causes: the 'external which has no fixed nature' and the 'internal' and 'self produced', which 'follows a definite order' (1979 [c. $110 \mathrm{BC}], 6.57$, p. 150). The latter, endogenous type of decay is the focus of

1 The term also started to become synonymous with bribery during this period. This latter, exclusively monetary meaning eventually replaced the Machiavellian meaning (Hirschman, 1977, pp. 40-1). 
Ferguson's concern (Ferguson, 1996 [1767]a, p. 212). Another important source for Ferguson is Stoicism. Stoic writings focused on the cultivation of virtues of 'life conduct' to be practised by both rulers and the ruled as a method for preventing corruption and for maintaining the strength and stability of the state. Consequently, their approach to political life was always highly normative and prescriptive (Robertson, 1983, pp. 137-8). Ferguson carefully studied and adopted Stoic ideas.

\section{Causes of degeneration}

Like Polybius before him, Ferguson sought to identify the variables leading to imperial atrophy. He relates corruption to changes in conditions that work to debase civic 'spirit': specialisation, overextension and hedonism. Though many of Ferguson's insights here are prescient of much nineteenth-century sociology (Hill, 1996), his aetiology of modern corruption is linked to his views on the causes of the decline of Republican Rome, all of which could be traced, in turn, to the triumph of Epicureanism over Stoicism. Epicureanism described a godless world governed by chance, reduced morality to hedonism and taught that 'all good was private'. Devotion to its tenets resulted in prodigality and ruination (Ferguson, 1834 [1783], pp. 169-70, 305-6), while the cure lay in the teachings of Stoicism (p. 170).

Ferguson tells us that 'nations cease to be eminent' when the citizen's active nature is deprived of 'objects which served to excite (his) spirit' (Ferguson, 1996 [1767]a, p. 200). A healthy state needs a vigorous, civically virtuous and active public; without it, dissipation sets in and despotism soon follows. History teaches that nations characterised by high levels of political apathy are extremely susceptible to despotic and praetorian rule. This fear of 'military government' was a longstanding one and is constantly reiterated in all Ferguson's published works and private correspondence.

Another major cause of corruption is overextension: the growth of small-scale communities into impersonal, unwieldy cities and empires (Ferguson, 1996 [1767] a, p. 257). The tendency towards urbanisation is exacerbated by an overzealous enlargement of state territory; both trends lead to over-bureaucratisation, overcentralisation and loss of social intimacy.

The newly emerging commercial ethic was also a major source of corruption. As Ferguson saw it, the commercial imperative erodes communal sentiments, while the division of labour brings on bureaucratisation. Both tendencies limit mass engagement in civic life (1996 [1767]a, p. 178). Due to the ever-increasing refinement of task specialisation, individuals become alienated from public affairs 
and tend to withdraw into their private, individuated, commercial concerns. To use Ferguson's terminology, the 'separation of professions...loosen(s) the bands of political union' (pp. 206-9).

Perhaps most importantly, specialisation means professional standing armies. This tendency erodes martial and communal ardour and undermines social cohesion. The loss of martial virtue is fatal to the moral personality. Ferguson lavishly idealised the warrior-statesman of classical reports, insisting that citizens should also be soldiers (1996 [1767]a, p. 149). Lamenting the increasing 'effeminacy' of commercial cultures, he insisted on the naturalness of our belligerent tendencies, arguing that they serve a valuable function in the formation of the moral personality by 'furnish[ing] a scene for the exercise of our greatest abilities'. These qualities 'are sentiments of generosity and selfdenial that animate the warrior in defence of his country' (p. 28). The use of standing armies deprives a people of their military valour (Ferguson, 1996b, pp. 142-3), their 'dignity and strength' (1756, p. 13), their enjoyment of the highest virtues and, in the end, national security itself (p. 36).

Coupled with the new spirit of commercialism, the division of labour causes 'members of a community...to lose the sense of every connection'. They have 'no common affairs to transact but those of trade', therefore 'the national spirit... cannot be exerted'. Ferguson compares commercial society unfavourably with simple or 'barbarous' nations where 'the public is a knot of friends' bound by a sense of common danger (Ferguson, 1996 [1767]a, p. 208).

Perhaps surprisingly, Ferguson rejects out of hand neither progress nor commercialism, because both are natural, inevitable and even designed events (see, for example, Ferguson, 1792, p. 199, 1878 [1769], pp. 90, 126). Rather, the best way to avoid impending political slavery is to offset the ill effects of progress by enhancing civic competence and awareness (Ferguson, 1996 [1767]a, p. 224; Wilkie, 1962, p. 172). In order for nations to be 'powerful and safe, they must strive to maintain the courage and cultivate the virtues of their people' (Ferguson, 1996 [1767]a, p. 61). It is not enough to simply have sound 'political establishments'; rather, the integrity of a constitution lies ultimately in the hands of the public and in its 'firm and resolute spirit' (p. 266) and determination to 'resist indignities' (p. 251). Political elites must devise the proper political arrangements by which inactive and apathetic citizens are distracted from their narrow, self-regarding concerns and enabled to redirect their attention to the public sphere (McDowell, 1983, pp. 546-7).

Citizen militias are one answer (Ferguson, 1996b, pp. 141-51) and one that Smith basically opposed (see below). Another is the encouragement of political activism and conflict but only within the context of a mixed constitution (Ferguson, 1834 [1783], p. 407, 1996 [1767]a, p. 252). Ferguson endorses the argument first set out 
by Polybius that the Romans maintained free constitutions 'not... by means of abstract reasoning, but rather through the lessons learned from many struggles and difficulties' and through the adoption of reforms indicated by 'the light of experience' (Polybius, 1979 [c. 110 BC], p. 311). Similarly, Machiavelli saw '[c] onflict, dissensions and even enmity' as 'the natural stuff of politics' (Shumer, 1979 , p. 14). ${ }^{2}$ According to Ferguson, although factional 'divisions...seem to endanger' the very existence of society, in fact it is faction that preserves its vitality by providing postures and roles for 'the scene that is prepared for the instruction of its members' (Ferguson, 1792, 1, p. 267). Ferguson goes so far as to endorse Plutarch's advice that legislators should deliberately encourage factional dispute. ${ }^{3}$ So long as factional conflict is tolerated, accommodated and perhaps even encouraged, there will always be 'wise establishments' advantageous to 'Liberty and Just Government' (Ferguson, 1756, p. 2).

\section{Smith's approach}

A number of scholars have argued that Smith shares Ferguson's apparent pessimism about the corrupting tendencies of the commercial age (see, for example, Alvey, 1998; Brown, 1994; Rosenberg, 1965; Winch, 1997) and even that he perceives in 'capitalism' the seeds of its own inevitable destruction (Heilbroner, 1973; Pack, 1991). This is likely an overstatement of Smith's position, as will be shown.

\section{Causes of corruption}

Although Smith does show an interest in the link between economic growth and corruption, his conception is far from classical. In general terms, since the forms of corruption he identifies could all be described as sins against protoliberal sensibilities, it is fair to say that he was working towards a 'modern' conception of the term. Eighteenth-century politics has been characterised as 'a racket, run by particular groups within the ruling classes largely for their own benefit' (Corrigan \& Sayer, 1985, p. 89). In a sense, most proto-liberalism was, almost by definition, an implicit reaction to such corruption (understood here in its modern sense) and Smith can, with confidence, be described as a proto-liberal, due to his concerted defence of such standard liberal values as impartiality, universalism, neutrality, formal equality of opportunity and rule of law in his campaign against corruption.

2 A section of the Discourses is even entitled 'That discord between the Plebs and the Senate of Rome made this republic both free and powerful' (Machiavelli, 1998, I.4, p. 113).

3 Ferguson paraphrases Plutarch here: '(G)ood citizens should be led to dispute' (Ferguson, 1996 [1767]a, p. 63). 
Yet his analysis does embody two features typical of a classical approach. The first is the broadness of his definition of corruption, which is not restricted to violations of the public interest by its servants, but which is understood as a condition capable of radiating diffusely throughout entire societies, permeating all its formal and informal institutions. Second, Smith clearly has in mind the standard classical dichotomy of the healthy versus the corrupt republic, ${ }^{4}$ and even agrees that the former is upheld by the virtue of its members and not simply its leadership. But it is important to be aware that such virtue is no recognisable classical type and that his good republic bears little or no substantive resemblance to the classical ideal. In fact, it is a comparatively tepid model, politically speaking, relying as it does on a well-regulated leadership and a quiescent, orderly, self-governing public. While Smith is definite that virtue is the main guard against social and economic corruption, the virtues he valorises and promotes are private and commercial rather than civic, otherregarding ones: the tame, cool virtues of the 'middling' ranks. These are the virtues of prudence, justice, propriety, self-command, frugality, sobriety, vigilance, circumspection, temperance, constancy, firmness, punctuality, faithfulness, enterprise and industry (Smith, 1976, III.5.8, p. 166, VII.ii.3.15, p. 304, 1979, II.iii.36, pp. 345-6). Moreover, and in direct contrast with Ferguson, they are generated outside politics and exclusivist social units like the extended family, ${ }^{5}$ the village, the umma or the feudal estate. Instead, they are forged in the impersonal, universalistic marketplace of commercial strangers.

The good polity is the natural market economy of self-regarding, lawful and mutually forbearing agents. Moral corruption does not arise from political apathy, selfishness or an inattention to the public sphere (as per classical and Fergusonian accounts) but is a product of a variety of sources that Smith regarded as outmoded remnants of a pre-commercial age - namely, institutional and legal impediments to the development of independent moral character (monopolies, poor laws, corporation laws, apprenticeship laws and regulations governing the institutions of entail and primogeniture) as well as political zealotry and factional conflict. These sources could not only corrupt individual agents but they could also threaten the prosperity and security of entire nations. Although it should be noted that Smith identifies an additional and genuinely 'modern' source of moral corruption (the division of labour), he insists that its effects are far from fatal and could be satisfactorily addressed within existing social arrangements (to be discussed further).

4 As Shumer (1979) notes: 'Corruption must be understood in relationship to its mirror-image concept, the healthy republic' (p. 8).

5 The nuclear family is, however, still seen to play a key role in the development of moral character. 
Perhaps Smith's idea of corruption can be best understood in the technical dictionary sense, as a deviation from a sound or natural condition. ${ }^{6}$ Smith does not really posit an ideal (sound) constitution or polity either from which societies deviated or towards which societies should gravitate. He is more interested in deviations from a state properly regulated by spontaneous laws of nature that he believed governed the entire universe, including societies, economies and even individual agents. There is a natural, spontaneous order that should not be interfered with - namely, the system of natural liberty and the market.

\section{The system of 'natural liberty': The market as a natural, uncorrupted order}

For Smith, beneath the complex of artificially imposed institutional constraints on human behaviour there exists a system of natural and spontaneous economic relations, which, when allowed to, functions harmoniously. In the system of 'natural liberty' each person is by nature the best judge of her own interest and should therefore be left unhindered to pursue it in her own way. In this manner, she is able to achieve not only her own best advantage, but that of society as well. In the spontaneous order of the market, government can rarely be more effective than when it is restrained and, for the most part, absent (Smith, 1979, IV.ix.51, pp. 687-8). Neither should monolithic private entities like the East India Company presume to interfere in the regular and self-equilibrating rhythms of this order. Smith regards interference with these spontaneous physics as a form of corruption - that is, a rebellion against nature; meddling from an assumed Archimedean perspective is extremely hurtful to 'the natural state of commerce' (Smith, 1978, [B], 306-7, p. 529).

Economic agents must be permitted the freest possible use of their bodies, minds and properties, provided that they do not themselves violate either the public interest or the system of natural liberty. Smith condemned regulations such as poor laws, corporation privileges, statutes of apprenticeship and restrictions on international trade as violations of a person's 'natural' rights (1979, IV.ix.51, p. 687). England's poor laws (and to a lesser degree its corporation laws) were the most pernicious constraint on such freedoms and were detrimental to both individual and public welfare. ${ }^{7}$ Similarly, the laws of apprenticeship were egregious, not only because they were an impediment to the mobility of labour, but also because of their tendency to discourage industry and commercial effort (Rosenberg, 1960, p. 561; Smith, 1979, I.x.c. 14-16, pp. 139-40).

\footnotetext{
6 As Mark Philp (1997) notes, the term corruption is 'rooted in the sense of a thing being changed from its naturally sound condition, into something unsound, impure, debased, infected, tainted, adulterated, depraved [or] perverted' (pp. 24-5).

7 Poor laws were more pernicious than corporation laws because they disproportionately disadvantaged the poor (Smith, 1979, I.x.c.44-5, p. 152).
} 
Other corrupting obstructions are typified by the partial and particularistic laws of entail and primogeniture, which Smith describes as 'contrary to nature, to reason, and to justice' (1978, [A], i.116, p. 48), 'founded' as they are 'upon the most absurd of all suppositions...that every successive generation of men have not an equal right to the earth, and to all that it possesses' (1979, III.ii.6, p. 384). Not only is this system of inheritance inequitable, it is also extremely maladaptive from an economic point of view due to its tendency to hinder agriculture and development (1979, III.ii.7, p. 385, III.iv.19, p. 423).

\section{'Dependency' and the violation of natural liberty}

Apart from their negative effects at the social-systems level, violations of the laws of natural liberty also have pernicious effects at the individual level on moral character. Once again, however, Smith's discussion of the corruption of moral character bears little resemblance to antique virtue discourses. His focus is on the preservation of commercial virtues such as economic independence, selfgovernment and enterprise. Dependency, in particular, is a key source of moral corruption, and Smith roundly condemns any paternalistic and dependencygenerating remnants of pre-commercial economic stages, most notably the necessary dependence associated with the feudal system of great landholders and retainers. 'Dependency' is pernicious because it breeds servility and fosters asymmetrical and therefore unhealthy and unproductive social relations (Smith, 1979, I.i.2, pp. 27, III.iv.4-7, pp. 412-15). Because of the poverty and indolence it promotes, dependency is also the source of all the 'disorder and confusions' that take place in cities. The best remedy is, of course, the expansion of 'commerce' (1978, [A], v.4-8, pp. 332-3). Because of its capacity to encourage 'independency', the growth of 'commerce and manufactures' is also 'the best police for preventing crimes' since '[n]o body will be so mad as to expose himself upon the highway, when he can make better bread in an honest and industrious manner' (1978, [B], 205, pp. 486-7).

Pre-commercial agents were limited by the fact that they had 'no other means of persuasion' by which to obtain their wants than to 'gain the favour of those whose service' was required. That meant having to resort to the debasing, inefficient and precarious method of 'servile and fawning attention' in order to 'obtain [the] good will' of others (1978, [A], vi.46-9, pp. 348-9). But in 'civilized society' agents are afforded greater independence, paradoxically, because each 'stands at all times in need of the co-operation and assistance of great multitudes'. The ability of humans to specialise and exchange the products of this specialisation makes them 'mutually beneficiall to each other' (1978, [A], vi.46-9, pp. 348-9). The dissolution of the system of great landholders decentralised dependency relations and offered greater security to individual tradespeople: now '[e]ach tradesman or artificer derives his subsistence from the employment, not of one, 
but of a hundred or a thousand customers.' This is a good thing because '[s/] he is not absolutely dependent upon any one of them' (1979, III.iv, p. 420). Rather than damaging the social fabric (as Adam Ferguson had suggested), specialisation generates unprecedented levels of mutuality. Associations are now increasingly voluntaristic, egalitarian and mutually beneficial - a matter of purely instrumental mutual 'good offices' (1979, I.ii.2, p. 26).

It is worth noting here that there is an initially confusing chapter of The theory of moral sentiments that Smith added to the sixth edition. In it, he seems to be suggesting that commercial life does, in fact, corrupt virtue. In an excursus on the apparently universal desire to emulate the rich via the pursuit of luxury status goods, Smith refers to this desire as a 'corruption' of virtue and 'our moral sentiments' as classically understood:

This disposition to admire, and almost to worship, the rich and the powerful, and to despise, or, at least, to neglect persons of poor and mean condition...is...the great and most universal cause of the corruption of our moral sentiments. That wealth and greatness are often regarded with the respect and admiration which are due only to wisdom and virtue; and that the contempt, of which vice and folly are the only proper objects, is often most unjustly bestowed upon poverty and weakness, has been the complaint of moralists in all ages.

Smith continues by observing with dismay that in polite society, all the best virtues are 'held in the utmost contempt and derision' (1976, I.iii.3, 6, p. 63). In the normal course of events the superficial trappings of greatness are the ones that are appreciated while real virtue goes unnoticed and unvalued. In these passages, Smith seems to echo Ferguson's classically inspired idealisation of warrior cultures: 'the frivolous accomplishments of that impertinent and foolish thing called a man of fashion, are commonly more admired than the solid and masculine virtues of a warrior, a statesman, a philosopher, or a legislator.' The admiration we reserve for 'mere wealth and greatness' seems morally suspect and yet it is an empirical fact that this is how the majority of people tend to think and behave (Smith, 1976, I.iii.3, 4, p. 62). People who aspire to imitate the 'envied situation' of the rich and great 'frequently abandon the paths to virtue' by using 'fraud and falsehood...intrigue and cabal' and all manner of criminal and antisocial means to attain their goal of 'greatness' (1976, I.iii.3, 7, 8, pp. 64-5). In fact 'avarice and ambition' are the causes 'of all the tumult and bustle, all the rapine and injustice' that have ever taken place in the world (1976, I.iii.2, 8, p. 57).

At first sight it looks as though Smith is invoking a classical conception of corruption in which the pursuit of personal glory and pleasure has corrupted virtue. In this vein, Ferguson had argued that the hero of the commercial age 
was a dubious, even dangerous, role model capable of infecting 'all orders of men, with equal venality, servility and cowardice' (Ferguson, 1996 [1767]a, p. 241). And yet it is telling that while Smith seems to lament the corruption of moral sentiments under commercialism, in the end he does not disavow it: quite the opposite. He goes on to explain that, although the rich and great are not really worthy of the admiration they attract, the fact of the matter is that 'they almost constantly obtain it', signifying that they must be 'in some respects, the natural objects of it' (Smith, 1976, I.iii.3, 4, p. 62, my emphasis). Reading on, we begin to appreciate that the apparent affinity between Smith and Ferguson is only superficial, because Smith soon defends our worship of the wealthy in terms of vital social functions. First of all, our innate regard for the trappings of wealth and greatness (which fuels the work and saving motivation) is a deliberate 'deception' that has been incorporated in the human constitution for specific ends: 'It is as well that nature imposes upon us in this manner' for it 'is this deception which rouses and keeps in continual motion the industry of mankind' (1976, V.i.7-10, pp. 181-3, my emphasis). Second, our tendency to worship the rich and powerful is 'necessary both to establish and maintain the distinction of ranks and the order of society' (1976, I.iii.1, p. 61). Third, our instinctive admiration of the rich produces the unanticipated social benefit of instilling in the masses appropriate authority values. Smith notes that the 'undistinguishing eyes' of 'the great mob of mankind' are incapable of distinguishing a wise and virtuous person from a foolish and vicious one, yet they can easily detect the presence of wealth (1976, VI.ii.1, 20, pp. 225-6). We have therefore been endowed with a reverence for those qualities immediately appreciable to even the most unsophisticated amongst us and this reverence provides a basis for leadership. Smith applauds the wisdom of nature in placing the burden of leadership, not as we might imagine, upon the shoulders of the wise and virtuous, but upon those of the rich. Smith is well aware that the rich are no more morally fit for leadership than the poor, but he does regard them as better equipped practically because they are generally better educated and more familiar with the trappings and protocols of authority than are the poor (1976, I.iii.2.5, p. 55).

The corruption of our moral sentiments is not really a form of corruption after all, not even in the classical corruption-of-virtue sense. What Smith really means is that it only appears that way. Ultimately, any disavowal of the impulse to admire prosperity and despise the failures of the poor would be counter to the decrees of 'nature' (1976, I.iii.2, 1, pp. 51-3) ${ }^{8}$ and even the moral judgments of the impartial spectator (1976, VI.i.11, p. 215). ${ }^{9}$ The pursuit of riches is both

8 It seems that it was '[p]rovidence who first divided the earth among a few lordly masters' (1976, IV.i.10, p. 185).

9 The impartial spectator allows us to see ourselves as others see us so that our self-interest never gets out of hand and our behaviour is never unsociable, thereby enabling us to maintain the sympathy, and therefore 
natural and morally acceptable. All that Smith requires is that it takes place within the bounds of natural liberty, positive justice and the limits set by the impartial spectator (Smith, 1976, II.ii.1, p. 83).

\section{The division of labour}

Another topic on which Smith seems to be displaying a concern with corruption as classically understood is in his discussion of the effects of specialisation under commercial conditions.

Smith's discussion of the division of labour is noteworthy not least because it is one of the few sources of corruption he identifies as peculiar to or induced by the commercial age. Significantly, though, its maladaptive aspects are perceived neither as unnatural nor as breaches of proto-liberal values.

Smith appreciated the alienating effects of the division of labour and his comments here are genuinely prescient. The division of labour reduces the tasks of workers to one or two simple operations, and, since work is central to intellectual development, the labourer naturally loses the good part of her cognitive capacities, including natural inventiveness. Workers' physical capacities are also impaired: task separation limits the labourer's scope of duties and renders 'him' 'incapable of exerting his strength with vigour and perseverance, in any other employment than that which [s/]he has been bred'. The individual thus acquires 'greater dexterity at his own particular trade' but only at the expense of 'his intellectual, social and martial virtues' (Smith, 1979, V.i.f.50, p. 782).

The worker involved in detail labour is reduced to a kind of automaton, who is not only 'as stupid and ignorant as it is possible for a human creature to become', but is also soon bereft of any capacity to exercise her judgment or moral perception (1979, V.i.f.50, pp. 781-2). Martial virtue is a further and significant cost of specialisation. Smith was uncharacteristically animated on this point, describing the coward as a kind of 'lepe[r]' who is 'mutilated and deformed in his mind' (1979, V.i.f.60, pp. 787-8).

\section{A pessimistic Smith?}

Because of these extremely negative and apparently pessimistic observations, it has been suggested that Smith's comments on the division of labour 'constitute a major source of inspiration for the socialist critique' of capitalism(Rosenberg, 1965,

cooperation, of others (1976, II.ii.1, p. 83, III.5, 5, p. 165). Smith states that it is the role of the 'impartial spectator' to perpetually monitor and correct the 'strongest impulses of self-love' (1976, III.3, 38, p. 153-4, III.3, 4, p. 137, VI.iii.18, pp. 244-5). 
p. 127). It has even been argued that Smith's comments should be interpreted as a sign that he anticipated the decline and eventual annihilation of the commercial regime (Heilbroner, 1973; Pack, 1991). Such claims are controvertible. To the extent that Smith's outline of the dehumanising consequences of specialisation on workers hints at the effects of fragmentation and product alienation, it is true that it does indeed foreshadow Marx's discourse on the same subject, ${ }^{10}$ but the parallels should not be overestimated. Like Ferguson, Smith registers the drawbacks of specialisation but never recommends any devolvement in specialisation functions, believing that its attendant problems could be solved within existing social and political arrangements (see below). And unlike Marx, Smith regards specialisation as a natural development originating in our natural desire to 'truck, barter and exchange' (Smith, 1979, I.ii.2, p. 26) and in our inventive, progressive faculties.

Further, Smith sees the mind-numbing effects of the division of labour as of relatively low importance in the grand scheme of things. At a more general social level, the entire system of commercialism and specialised labour generates great levels of liberty and independence for all members of society, including the working poor. It also delivers better security and is the source of almost all of the progress and prosperity of the commercial age (see, for example, 1979, I.i.10-11, pp. 22-4). This is significant because for Smith, the happy society is the prosperous, materially abundant society (1976, I.iii.2, 1, p. 51, III.5, 7, p. 166, 1979, I.V.iii.36, p. 96). He generally takes the view that whatever makes a country rich - and the division of labour does this better than anything elseenriches the poor as well and is therefore, in the long view, to their benefit (1978, [B], 212-13, pp. 489-90, Early draft of The wealth of nations, 5-6, in Smith, 1978, pp. 563-4). Thus, on balance, and despite any ill effects, the division of labour yields more, rather than less, human happiness all round.

From Smith's point of view the main problems with the division of labour are not the loss of civic virtue or the imminent collapse of commercialism itself, but its entirely ameliorable consequences for public order and personal comportment. To this end, he advocated the establishment of a compulsory and publicly funded school system to inculcate patterns of civility suitable for market-society subjects (1979, V.i.i.5-6, p. 815, V.i.f.57, p. 786, V.i.f.54, p. 785). An educated people are 'more respectable' and orderly because they are more inclined to acknowledge the authority of their 'lawful superiors'. They are also 'more capable of seeing through the interested complaints of faction and sedition' (1979, V.i.f.61, p. 788) and therefore less easily roused to political tumult.

10 As first noticed by David Kettler (1965, pp. 8-9). 


\section{Faction}

Another aspect of Smith's approach to corruption, and one that further distances him from classical (and Fergusonian) approaches, is his attitude to political conflict in general and to political factions in particular. Contrary to Ferguson's view, faction fighting neither enhances civic virtue nor in any way preserves just government (Smith, 1976, III.3.33, p. 151). Factions have a tendency to 'deceive and impose upon the Public' and to 'oppress' rather than serve government (Smith, 1987 [1785], p. 286). Dispute between political factions 'distract[s] the nation' and corrupts the 'moral sentiments' (1976, III.3.43, p. 155-6). ${ }^{11}$ The behaviour of factions is generally 'atrocious', violent and unjust (1976, III.3.25, p. 231, V.iii.12, p. 242), and they invariably exacerbate sectarian conflict (1979, V.i.g.7, pp. 791-2). Smith disparaged all forms of conflict and social disharmony, insisting that ' $\mathrm{t}]$ he peace and order of society, is of more importance than even the relief of the miserable' (1979, V.i.ii.1, 20, p. 226, VI.ii.2, 12, p. 231). Contrary to Ferguson's enthusiastic promotion of mass activism and political turbulence, Smith wanted to see a dampening, a professionalisation and institutionalisation, of political spirit. Once a sound constitution has been put in place, ${ }^{12}$ politics seems to have been reducible to two main functions: the rational administration of populations, and the management of the practical exigencies of security, both economic and military. ${ }^{13}$

The differences between Smith and Ferguson on the issue of conflict underline their more general differences in terms of traditions. Smith signals his allegiance to progress and modernity when he draws upon the doux commerce thesis popularised by Montesquieu. In this view, progress and commercialism have a positive, softening effect on manners. With the new politeness and civility comes also an aversion to war and all other forms of conflict. Smith regards emotions such as hatred, resentment, revenge and anger as 'unsocial' passions that 'poison...the happiness of a good mind' (1976, I.ii.3.7, p. 37). As such, they needed to be reined in and kept within the bounds of civility and justice. Smith disliked all forms of conflict including war (Hill, 2009). Ferguson, on the other hand, tended to idealise war, perceiving it as an opportunity to exercise the classical martial virtues and to enhance social cohesion. Even as Smith was celebrating the pacifying effects of progress and commerce, Ferguson was still writing nostalgically of those '[s]mall and simple tribes' whose conflicts with out-groups were 'animated with the most implacable hatred' (Ferguson, 1996 [1767]a, p. 25).

\footnotetext{
11 Hume agreed (see 1987 [1774], p. 171).

12 Such a constitution would be characterised by features such as the separation of powers (1979, V.i.b.25, pp. 722-3).

13 As reported by Dugald Stewart from a document no longer in existence in his Account of the Life and Writings of Adam Smith in his Collected Works, ed. Sir William Hamilton, 1858, Vol. X, p. 68' (Winch, 1978, p. 4, n. 2).
} 


\section{Concluding remarks}

Whereas Ferguson's aetiology of corruption fits fairly readily within corruption traditions, Smith's approach is more modern. Contrary to Ferguson's account, Smith did not think that hedonism (Epicureanism), privatisation, civic quiescence and the breakdown of exclusivist social categories were the problem. In fact, they might even be the solutions to the potentially corrupt state.

Ferguson tended to look to the past for remedies to the problems of modernity. He hoped to reconstitute national identity, social intimacy and civic virtue through a kind of cultural atavism, coupled with such practical measures as citizen militias and political institutions for the safe discharge of factional conflict. But Smith regards these strategies as remnants of a pre-commercial age that ought to be purged in order to prevent corruption. Similarly, while Ferguson observes with dismay the increasing depersonalisation, dispassion and impartiality of the commercialising state, Smith embraces such developments with enthusiasm.

Though Smith was keenly aware of 'the disadvantages of a commercial spirit', he seems more convinced that commercialisation is natural, inevitable and basically positive. His views are ultimately those of an early liberal and classical political economist, so corruption is seen as a deviation from a natural (broadly liberal) state. Ferguson, by contrast, though in many respects a friend to progress, is reluctant to abandon a civic-humanist diagnostic tradition that stressed the value of personalism, particularism, community, martial virtue and intense forms of interdependence.

\section{Acknowledgements}

The author wishes to thank the Australian Research Council whose generous funding for DP0770499 made the completion of this chapter possible. She also thanks her research assistant, Kelly McKinley, for her able assistance.

\section{References}

Alvey, James. (1998). Adam Smith's three strikes against commercial society. International Journal of Social Economics, 25(9), 1425-41.

Brown, Vivienne. (1994). Adam Smith's discourse. London: Routledge. 
Corrigan, Philip, \& Sayer, Derek. (1985). From theatre to machine: old corruption. In Philip Corrigan \& Derek Sayer (Eds), The great arch: English state formation as cultural revolution (pp. 87-113). Oxford: Basil Blackwell.

Ferguson, Adam. (1756). Reflections previous to the establishment of a militia. London: R. \& J. Dodsley.

Ferguson, Adam. (1792). Principles of moral and political science: being chiefly a retrospect of lectures delivered in the College of Edinburgh. London and Edinburgh: A. Strahan \& T. Cadell, and W. Creech.

Ferguson, Adam. (1834 [1783]). The history of the progress and termination of the Roman republic. London: Jones \& Company.

Ferguson, Adam. (1878 [1769]). Institutes of moral philosophy. New York: Garland Publishing Company.

Ferguson, Adam. (1996 [1767]a). An essay on the history of civil society. Fania OzSalzberger (Ed.). Cambridge: Cambridge University Press.

Ferguson, Adam. (1996b). Separation of departments. In Yasuo Amoh Kyoto (Ed.), Collection of essays (pp. 141-51). Kyoto: Rinsen Book Company.

Heilbroner, Robert. (1973). The paradox of progress: decline and decay in The Wealth of Nations. Journal of the History of Ideas, 34, 243-62.

Hill, Lisa. (1996). Anticipations of nineteenth and twentieth century social thought in the work of Adam Ferguson. European Journal of Sociology, 37(1), 203-28.

Hill, Lisa. (2009). Adam Smith on war (and peace). In Ian Hall \& Lisa Hill (Eds), British international thinkers from Hobbes to Namier (pp. 71-89). New York: Palgrave Macmillan.

Hirschman, Albert O. (1977). The passions and the interests: political arguments for capitalism before its triumph. Princeton: Princeton University Press.

Hume, David. (1987 [1774]). Letter 141 from Hume to Smith, St Andrew's Square, 13 February 1774. In E. C. Mossner \& I. S. Ross (Eds), The correspondence of Adam Smith. Oxford: Oxford University Press.

Kettler, David. (1965). The social and political thought of Adam Ferguson. Indiana: Ohio State University Press.

McDowell, Gary L. (1983). Commerce, virtue and politics: Adam Ferguson's constitutionalism. Review of Politics, 45(4), 536-52. 
Machiavelli, Niccolò. (1998). The discourses. Edited and with an introduction by Bernard Crick. Suffolk: Penguin.

Pack, Spencer J. (1991). Capitalism as a moral system: Adam Smith's critique of the free market economy. Aldershot: Edward Elgar.

Philp, Mark. (1997). Defining political corruption. In P. Heywood (Ed.), Political corruption (pp. 20-46). Oxford: Blackwell.

Pocock, J. G. A. (1975). The Machiavellian moment: Florentine political thought and the Atlantic republican tradition. Princeton: Princeton University Press.

Polybius. (1979 [c. 110 BC]). The rise of the Roman Empire (Ian Scott-Kilvert, Trans.). Selected and with an introduction by F. W. Walbank. London: Penguin.

Robertson, John. (1983). The Scottish Enlightenment at the limits of the civic tradition. In I. Hont \& M. Ignatieff (Eds), Wealth and virtue: the shaping of political economy in the Scottish Enlightenment. Cambridge: Cambridge University Press.

Rosenberg, Nathan. (1960). Some institutional aspects of The Wealth of Nations. Journal of Political Economy, 69, 557-70.

Rosenberg, Nathan. (1965). Adam Smith on the division of labour: two views or one? Economica, 33, 127-39.

Shumer, Sara M. (1979). Machiavelli: republican politics and its corruption. Political Theory, 7(1), 5-34.

Smith, Adam. (1976). The theory of moral sentiments. D. D. Raphael and A. L. MacFie (Eds). Oxford: Clarendon Press.

Smith, Adam. (1978). Lectures on jurisprudence. R. L. Meek, D. D. Raphael and L. G. Stein (Eds). Oxford: Oxford University Press.

Smith, Adam. (1979). An inquiry into the nature and causes of the wealth of nations. R. H. Campbell and A. S. Skinner (Eds). Oxford: Clarendon Press.

Smith, Adam. (1987 [1785]). Letter 248 addressed to Le Duc de la Rochefoucauld, Edinburgh, 1 November 1785. In E. C. Mossner \& I. S. Ross (Eds), The correspondence of Adam Smith. Oxford: Oxford University Press.

Wilkie, Jean. (1962). The historical thought of Adam Ferguson. Unpublished doctoral dissertation. Washington, DC: The Catholic University of America.

Winch, Donald. (1978). Adam Smith's politics. Cambridge: Cambridge University Press.

Winch, Donald. (1997). Adam Smith's problem and ours. Scottish Journal of Political Economy, 44, 384-402. 